\title{
VOLUMETRIC AND ECONOMIC OPTIMAL ROTATIONS FOR FIREWOOD PRODUCTION OF Eucalyptus urophylla IN IPAMERI, STATE OF GOIAS
}

\author{
José Imaña-Encinas ${ }^{1}$, Otacílio Antunes Santana ${ }^{2}$, Christian Rainier Imaña ${ }^{3}$ \\ ${ }^{1}$ Eng. Florestal, PhD, Prof. Depto. Engenharia Florestal, UnB, Brasília, DF, Brasil - imana@unb.br \\ ${ }^{2}$ Biólogo, Dr., Depto. Geografia, UnB, Brasília, DF, Brasil - otaciliosantana@ gmail.com \\ ${ }^{3}$ Estatístico, Sec. de Fazenda do Estado de Minas Gerais - christian_bsb@hotmail.com \\ Recebido para publicação: 13/07/2010 - Aceito para publicação: 12/06/2011
}

\begin{abstract}
This work analyzes the volumetric and economic production of Eucalyptus urophylla S. T. Blake stands oriented to firewood production in a three-years cutting cycle, in the region of Ipameri, State of Goias. 1,545 trees were measured and rigorously scaled. The volume data obtained was adjusted by Schumacher log-reciprocal model. The volumetrically optimal rotation was defined by the Mean Annual Increment and Land Expectation Value maximization criteria. The optimal rotation ages were between 5 and 6 years, and the economically optimal rotations were around 3 years of age. In relation to the sampled data, it may be inferred that the optimal harvest age should be at age 4 .

Keywords: Biological rotation age; increments; forest management.
\end{abstract}

\section{Resumo}

Rotações volumétrica e econômica ótimas para produção de lenha de Eucalyptus urophylla em Ipameri, estado de Goiás. Este trabalho analisa a produção volumétrica e econômica de talhões de Eucalyptus urophylla $\mathrm{S}$. T. Blake destinados à produção de lenha em ciclos de corte de três anos, na região de Ipameri, Goiás. Foram medidas e posteriormente cubadas rigorosamente 1.545 árvores. Os volumes obtidos foram ajustados ao modelo log recíproco de Schumacher. Obteve-se a otimização da rotação volumétrica pela maximização do incremento médio anual e do valor esperado da terra. As rotações volumetricamente ótimas identificaram a idade entre 5 e 6 anos, e as rotações economicamente ótimas ficaram em torno de três anos de idade. Com base nos dados coletados, se infere que a rotação ótima de corte deveria ficar na idade de 4 anos.

Palavras-chave: Idade de corte; incrementos; manejo florestal.

\section{INTRODUCTION}

Extensive and well conducted industrial reforestations with Eucalyptus spp. has guaranteed the constant and regular supply of several industries that process and consume these plantations' raw materials, in the country. The relatively low cost of implantation and correspondent maintenance of these reforestations, with a continuous wood production within a short period, allied to the excellent soilclimatic conditions within which the eucalypt grows in Brazil, have positioned the reforestation-based forest industry in the group of investment opportunities of highest competitiveness (RODRIGUEZ; DIAZ-BALTEIRO, 2006; RODRIGUEZ et al., 1997). In order to the brazilian forest industry maintain itself growing and attracting new investors, within a more globalized and competitive world, the revision and the continuous analysis of bases to important management decisions are essential (AMS, 2010).

In the industrial reforestations specific case, a stand's harvest age represents unreservedly one of the main decision variables for the correspondent forest management plans. The harvest rotation age definition requires an independent analysis for each stand, even though it is connected to the production of every stand in the forestry enterprise. The correct definition of the harvest age results, usually, in a complex task that must involve a coherent and complex processing of a lot of information (RODRIGUEZ et al., 1997; BUONGIORNO; GILLESS, 1987).

In several countries with forestry tradition, likewise Germany, operational management and research specialists use the most modern and updated computer resources to maximize and generate solid 
and consistent forest management plans. These plans normally analyze the whole forest, even though they are based on information available only for one stand or area unit.

By definition, a forest planning system clearly details how the forest interventions should occur in each stand or area unit, mainly considering the consequences for the remaining forest. Within aggregate planning systems, the decisions of when, how and which area units or stands will be harvested should be made unfailingly based on long-term planning horizons, considering the forest structure, composition, availability, and other forest characteristics that are directly responsible for the enterprise global supply (RODRIGUEZ et al., 1997; CABANA, 1993; DAVIS; JOHNSON, 1987; GRESHAM, 1995).

Some forest planning systems used nowadays have made it difficult to analyze one single stand when the determination of the optimal harvest age and the best moment for silvicultural restoration are considered. Other forest planning systems, normally based on stands oriented to the provision of big forestry enterprises, based themselves on complex mathematical techniques along with the use of modern computer resources. There are many studies, likewise Rodriguez et al. (1997) Hoffmann and Vieira (1985), Leuschner (1990) and Little and Gardner (2003), which broach the matter of planning efficiency in order to transform closed forests in highly productive forests.

The optimal age per stand determination, without any bonding with the whole forest, will only be useful in situations where the forest management basic units may be considered independently, and not bonded to each other. However, it is observed that in industrial reforestations, many of the single-stand analysis techniques have been used indiscriminately and the generalization of these results may have created undesirable habits for the forestry enterprise. Suppose there is, within a large area, since few years, only one single harvesting age recommendation for the eucalypt, for instance, seven years. This type of recommendation practically disregards the rotation's dynamics (NEWMAN, 1988), the species' growth type, its linkage with respective global plans of supplying, the correspondent value increase due to gain in wood quality, the land value (REZENDE et al., 1994), as well as the use of different interest rates, among others.

Another concept that needs particular care in its efficiency is contrary to the idea of rotations defined by economic criteria be always smaller than those based on volumetric criteria, considering the maximum mean annual increment (RODRIGUEZ; DIAZ-BALTEIRO, 2006; RODRIGUEZ et al., 1997; RODRIGUEZ; MOREIRA, 1989). The decision of harvesting forest stands when the MAI (mean annual increment) is maximum is justified for resulting in a mean annual volume higher than the annual volume that would be obtained if this forest stands were harvested at any other age.

The aim of this work was to analyze volumetric and economical parameters of a Eucalyptus urophylla S. T. Blake plantation with a three-year cutting cycle, oriented to supply the firewood market. The considered hypothesis was if very short cutting cycle can be accepted into a volumetric and economic management system.

\section{MATERIALS AND METHODS}

The data was collected in a Eucalyptus urophylla S. T. Blake plantation of the "Brasil Verde Agroindustria" company, located in the municipality of Ipameri, State of Goias, more precisely at $16^{\circ} 11^{\text {' }}$ $40^{\prime \prime} \mathrm{S}$ and $47^{\circ} 19^{\prime} 45^{\prime}$ ' W - SAD'69. Some stands, when the data was collected, were in cut point for firewood production. It must be pointed that the company when the work was done, used, among others, a three-year cutting cycle, with exclusive orientation for firewood production.

Within the stands oriented to timber harvesting, 11 temporary plots of $30 \times 50 \mathrm{~m}$ were randomly established. In a 3 x $2 \mathrm{~m}$ spacing it was encountered around 150 trees per plot, distributed in 6 rows of 25 trees. In order to obtain the wood volume in $\mathrm{m}^{3}$, the dendrometric variables DBH outside bark and total height were collected from 1,545 live trees. The DBH outside bark was measured with an $80 \mathrm{~cm}$ caliper and the total height with a Haga hypsometer, $15 \mathrm{~m}$ distant from the tree. Afterwards, the 1,545 Eucalyptus urophylla trees were rigorously scaled.

For the graphical analysis of the volume-per-age projection, data were adjusted by Schumacher log-reciprocal model (1939):

$$
V=\alpha e^{\frac{\beta}{t}}
$$


where: $\mathrm{V}=$ volume

$\alpha$ and $\beta=$ model parameters

$\mathrm{t}=$ plantation age

From a strictly volumetric point-of-view, the optimal cutting age would be that which results in the higher at mean annual volume along with several rotations. This age is normally just before the point where the MAI - mean annual increment and CAI - current annual increment curves cross each other (IMAÑA-ENCINAS et al., 2005).

$$
\text { Maximize } M A I=\frac{V}{t}
$$

where: $\mathrm{MAI}=$ mean annual increment

$\mathrm{V}=$ volume produced as a function of age $t$

$\mathrm{t}=$ forest age (years).

From the first order condition:

$$
\frac{\partial M A I}{\partial t}=0 \Rightarrow\left(V^{\prime} t-V\right) / t^{2}=0 \Rightarrow V^{\prime}=V / t \Rightarrow C A I=M A I
$$

The result is expected to be the equality between the current annual increment (CAI) and the MAI, when MAI is maximized. Alternatively, it is valid to confirm that the MAI will be maximum when the growth relative rate is equal to the reciprocal of the forest stand age, which means:

$$
\frac{V^{\prime}}{V}=\frac{1}{t}
$$

For the economic method analysis, applying the Faustmann's formula established in 1849 (RIBEIRO, 1996), or the Land Expected Value (LEV), it is obtained the sum of the liquid income present value obtained at the end of the forest production cycles, which repeat themselves perpetually.

Graphically, an infinite series of rotations with $t$ years of duration would be represented this way:

$$
0-----t-----2 t-----3 t-----\infty
$$

The liquid income every $t$ years, considering the $I$ cost of implantation in the beginning of each rotation and the price $p$ per volume unit $V$ capitalized at instant rates, with nominal annual interest (r), would be equal to:

$$
p V-1 e^{r . t}
$$

Therefore, mathematically, it may be considered that the economic optimization recommends the age which maximizes the LEV, in other words, it seeks to (SCHONAU, 1991):

$$
\text { Maximize LEV }=\left(p V-I e^{r . t}\right)\left(e^{r . t}-1\right)^{-1}
$$

where: $\quad L E V=$ land expectation value (present value of the rotations infinite series)

$p=$ price per volume unit

$V=$ volume

$I e^{r . t}=$ cost of implantation in the year $t$, at an instantaneous interest rate

$\left(e^{r . t}-1\right)^{-1}=$ multiplier for the present value of perpetual periodic series. 
Alternatively, it is valid to suppose that the LEV will be maximum when there is a $t$ value which validates the following relation:

$$
\frac{V^{\prime}}{V-1 / p}=\frac{r}{1-e^{-r t}}
$$

The price-per-volume values, cost of implantation per year, and interest rates were compiled from the institutions that report these data and with them it was calculated a correspondent average, confirmed by Wood Resources International LLC (WRI) (2000) and Little (2003).

The volumetrically optimal rotation (VOR) was defined as the one for which the mean annual increment (MAI) is maximum. The VOR, therefore, is very influenced by growth presuppositions and by the chosen production model parameters. In the Schumacher log-reciprocal model's case, the coefficient $\beta$ directly expresses the age which maximizes $\mathrm{MAI}^{2}$.

The economically optimal rotation (EOR), considering this case, depends on three variables: $I$ (cost of implantation), $p$ (price per volume unit) and $r$ (annual interest rate). To instance the alterations' effect on these values it was used the Schumacher model, which was the base for the VOR determination.

\section{RESULTS AND DISCUSSION}

Applying Schumacher's equation to the collected data it was obtained the volume per age projection, with the regression coefficients $\alpha=750.199$ and $\beta=-5.877\left(V=750.199 e^{-5.877 / \text { years }}\right)$. From this mathematical expression it was created the correspondent volume graph $\left(\mathrm{m}^{3} / \mathrm{ha}\right)$ per age (years), as shown in figure 1.

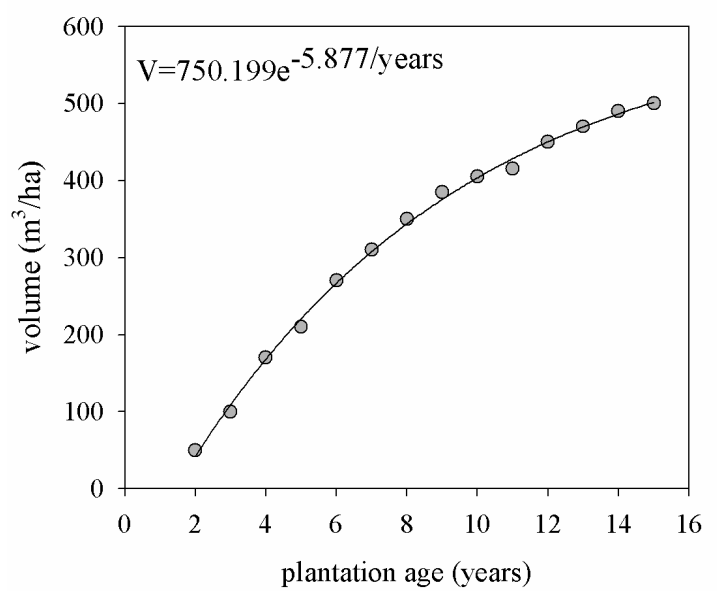

Figure 1. Volume adjusted by Shumacher's equation to the data of a three-year-old Eucalyptus urophylla plantation.

Figura 1. Equação volumétrica de Schumacher ajustada aos dados de um reflorestamento de Eucalyptus urophylla na idade de três anos.

For the adjusted data, it may be observed that the volume growth per year occurs almost linearly until the sixth year $\left(y=55 x-60 ; R^{2}=0.9951\right)$, whereas, afterwards, growth decays logarithmically $(y=$ $\left.240.73 \operatorname{Ln}(x)-149.87 ; \mathrm{R}^{2}=0.9887\right)$. The tendency curve shows that waiting several years for longcutting rotations is not an advantage in terms of volume. These conclusions are confirmed by Hofmann e Vieira (1985) and Bertolucci (1993), who worked with Eucalyptus. Data obtained from the increment calculation, derived from Schumacher's equation production curve, enabled the creation of CAI and MAI 
correspondent tendency curves, shown in figure 2. Through a traditional interpretation, the curve-crossing at age 6 would identify the optimal rotation age (IMAÑA-ENCINAS et al., 2005).

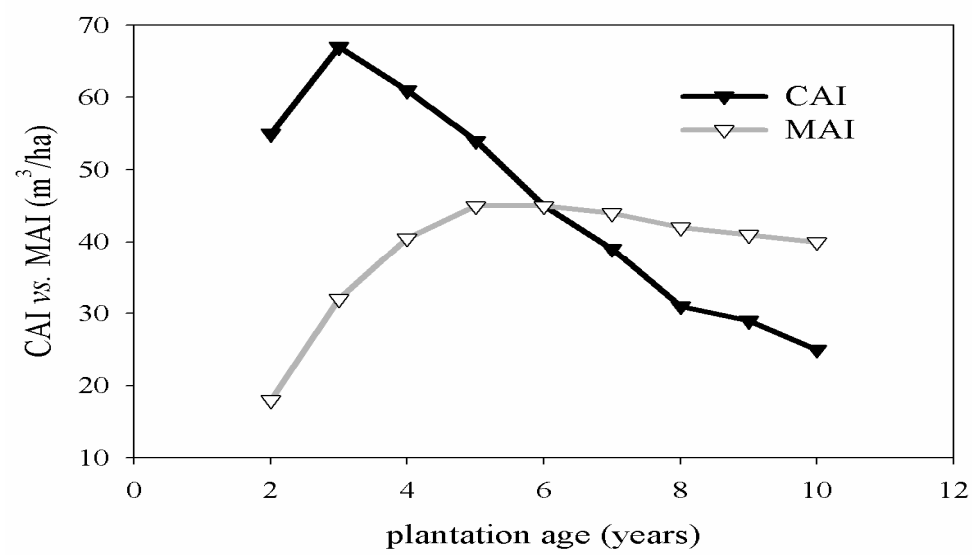

Figure 2. MAI (mean annual increment) and CAI (current annual increment) curves.

Figura 2. Curvas do IMA (incremento médio anual) e ICA (incremento corrente anual).

The correspondent curves analyses by volumetric and economic methods enabled to simultaneously obtain the volumetrically optimal rotations (VOR) and the economically optimal rotations (EOR), as shown in figure 3. It is observed that the optimal cycles in volumetric terms are between 5 and 6 years, fully justified by the previous analysis.

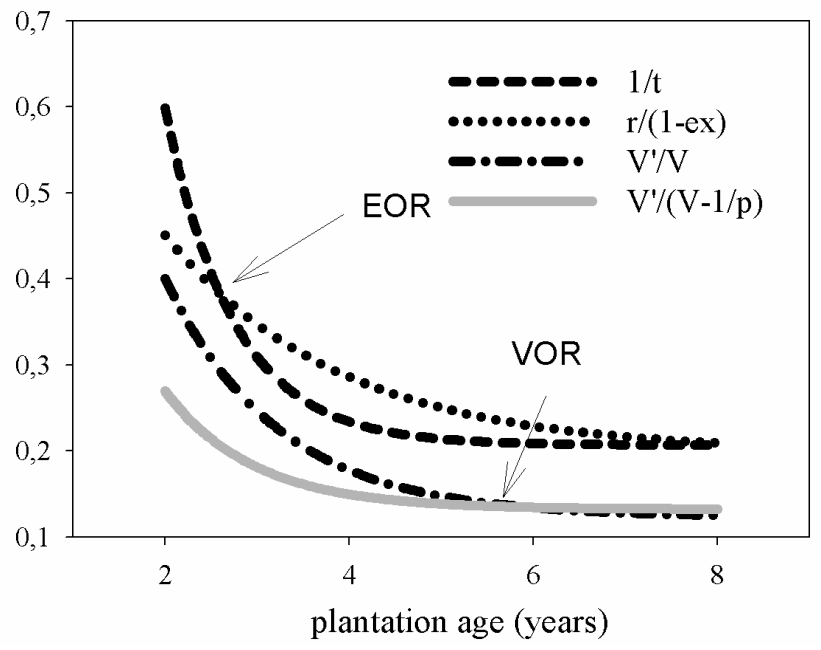

Figure 3. Economic-analysis equations' curves $\left[\mathrm{V}^{\prime} /(\mathrm{V}-\mathrm{I} / \mathrm{p})=\mathrm{r} /(1-\mathrm{ex})\right]$ and volumetric analysis $\left[\mathrm{V}^{\prime} / \mathrm{V}=\right.$ $1 / t$ ] which enabled the simultaneous determination of the volumetrically (VOR) and economically $(\mathrm{EOR})$ optimal rotations. $(\mathrm{V}=$ volume; $\mathrm{p}=$ price; $\mathrm{t}=$ years of capitalization at interest rate; $\mathrm{I}=$ investment).

Figura 3. Curvas das equações das análises econômica $\left[V^{\prime} /(V-I / p)=r /(1-e x)\right]$ e volumétrica $\left[V^{\prime} / V=1 / t\right]$, mostrando simultaneamente as rotações volumétricas e econômicas ótimas. ( $\mathrm{V}=$ volume; $\mathrm{p}=$ preço; $\mathrm{t}=$ anos da capitalização e juro; $\mathrm{I}=$ investimento $)$.

However, in the same analysis it was identified that EOR requires shorter cycles, of around 3 years, when the economic analysis' equation is considered (Faustmann's equation), where interest rates 
higher than the age reciprocal will maximize the MAI. This situation normally happens in the Brazilian firewood market (AMS, 2010), in such a way that graphic interpretation leads to recommend the stand's harvesting within a rotation shorter than the volumetrically optimal rotation.

Within the Eucalyptus stands analyzed, it may be inferred that the harvesting cycle should be at four years of age.

The graphical representation of the analyzed relations showed that the Eucallyptus urophylla shorter harvesting cycles are more economically interesting, first due to the low wood price valorization (Figure 3), and second because of a possible market demand, which is not satisfactory.

It also became evident the expectation of volumetrically optimal rotations being always closer to economically optimal rotations.

Through the economic analysis, if it were used interest rates lower than the reciprocal of the age which results in the maximum MAI, it should be necessarily considered: the correspondent implantation cost values, product price and growth model parameters, which proportionally influence the volumetric rotation to be longer than the economic rotation.

By this analysis, it may be confirmed that it would be more interesting if the cutting cycle was analyzed by the economically-optimal-rotations set for the correspondent eucalypt plantations, considering the optimization for the whole forest and not only for the stand in cut point, as it was carried out in this study.

\section{CONCLUSIONS}

Specifically for Eucalyptus stands oriented to firewood production, in the region of Ipameri, State of Goias, through the MAI maximization analysis it was possible to identify the volumetrically optimal rotation (VOR) of around 5 and 6 years, and the economically optimal rotation (EOR) of around 3 years, recommending a four-year cutting cycle. Through this conclusion the considered hypothesis was fully accepted.

\section{REFERENCES}

ASSOCIAÇÃO MINEIRA DE SILVICULTURA (AMS). Anuário estatístico 2009. Belo Horizonte: MAS, 2010. $23 \mathrm{p}$.

ASSOCIAÇÃO NACIONAL DOS FABRICANTES DE PAPEL E CELULOSE. Relatório estatístico 1993. São Paulo: 1993. 54 p.

BERTOLUCCI, F.; REZENDE, G.; PENCHEL, R. Produção e utilização de híbridos de eucalipto. Silvicultura, v. 13, n. 51, p. 12 - 18, 1993.

BINKLEY, C. S. When is optimal economic rotation longer than the rotation of maximum sustained yield? Journal of Environmental Economics and Management, v. 14, p. 152 - 158, 1987.

BRIGHAM, E. F.; HOUSTON, J. F. Fundamentals of financial management. 3. ed. Thomson International New York, 2002. p. 12D1 - 12D3.

BUONGIORNO, J.; GILLESS, K. Forest management and economics: a primer in quantitative methods. New York: McMillan, 1987. 285 p.

CABAÑA, C. El mercado interno de la madera. Chile Forestal, v. 205, p. 38 - 39, 1993.

DAVIS, L. S.; JOHNSON, K. N. Forest management. New York: Mc Graw-Hill, 1987. 790 p.

GRESHAM, G. E. Mercado de madeira de florestas plantadas. In: SEMINÁRIO INTERNACIONAL DA MADEIRA DE EUCALIPTO PARA SERRARIA, 1995, Piracicaba. Anais... Piracicaba: IPEF/IPTIUFRO/LCF-ESALQ-USP, 1995. p. 147 - 165.

HOFFMANN, R.; VIEIRA, S. Eucalyptus growth curves and the determination of the optimal cutting age. Revista de Econometria, p. 112 - 128, 1985. 
IMAÑA-ENCINAS, J.; SILVA, G. F. da; PINTO, J. R. R. Idade e crescimento das árvores. Brasília: Universidade de Brasília, Depto. Engenharia Florestal, 2005. 40 p. (Série Comunicações Técnicas Florestais, v. 7, n. 1).

LEUSCHNER, W. A. Forest regulation, harvest scheduling, and planning techniques. New York: John Wiley, 1990. 281 p.

LITTLE, K. M.; GARDNER, R. A. W. Coppicing ability of 20 Eucalyptus species grown at two highaltitude sites in South Africa. Can. J. For. Res., v. 33, p. 181 - 189, 2003.

NEWMAN, D. H. The optimal forest rotation: a discussion and annotated bibliography. USDA Forest Service, n. 48, p. 1 - 47, 1988. (SE General Technical Report).

REZENDE, J. L. P.; LOPES, H. V. S.; NEVES, A. R.; PAULA JR., G. G. A importância do custo da terra na determinação da idade ótima de corte de povoamentos de eucalipto. Revista Árvore, v.18, n. 1, p. $45-55,1994$.

RIBEIRO, C. A. A. S.; GRAÇA, L. R. Manejo por talhadias: estabelecimento das idades ótimas de corte. Revista Árvore, v. 20, n. 1, p. 29 - 36, 1996.

RODRIGUEZ, L. C. E.; DIAZ-BALTEIRO, L. Régimen optimo para plantaciones de eucaliptos en Brasil: un análisis no determinista. Interciencia, v. 31, n. 10, p. 739 - 744, 2006.

RODRIGUEZ, L. C. E.; BUENO, A. R. S.; RODRIGUES, F. A. Rotações de eucaliptos mais longas: análise volumétrica e econômica. Scientia Forestalis, v. 51, p. 15 - 28, 1997.

RODRIGUEZ, L. C. E.; MOREIRA, R. M. Gerenciamento de florestas de eucalipto com modelos de programação linear. Série Técnica IPEF, v. 6, n. 19, p. 1 - 15, 1989.

SCHONAU, A. P. G. Growth, yield and timber density of short rotation coppice stands of E. grandis. South African Forestry Journal, v. 156, p. 12 - 22, 1991.

WOOD RESOURCES INTERNATIONAL LLC (WRI). Global wood fibre market update. Disponível em: <http://www.wri-ltd.com/PDFs/WRQJuly2000.pdf>. Acesso em: 13/07/2010. 
Imaña-Encinas, J.; Santana, O. A.; Imaña, C. R. 